\title{
The Haiti Medical Education Project: development and analysis of a competency based continuing medical education course in Haiti through distance learning
}

Robert Battat ${ }^{*}$, Marc Jhonson ${ }^{2}$, Lorne Wiseblatt ${ }^{3}$, Cruff Renard ${ }^{4}$, Laura Habib ${ }^{5}$, Manouchka Normil ${ }^{6}$, Brian Remillard ${ }^{7}$, Timothy F. Brewer ${ }^{8}$ and Galit Sacajiu ${ }^{9}$

\begin{abstract}
Background: Recent calls for reform in healthcare training emphasize using competency-based curricula and information technology-empowered learning. Continuing Medical Education programs are essential in maintaining physician accreditation. Haitian physicians have expressed a lack access to these activities. The Haiti Medical Education Project works in alliance with Haitian medical leadership, faculty and students to support the Country's medical education system. We present the creation, delivery and evaluation of a competency-based continuing medical education curriculum for physicians in rural Haiti.

Methods: Real time lectures from local and international institutions were teleconferenced to physicians in remote Haitian sites using VidyoConferencing ${ }^{\text {TM }}$ technology. With American Academy of Family Physicians (AAFP) and College of Family Physicians Canada (CFPC) guidelines as references, a competency-derived syllabus was created for a Haitian continuing medical education program. The resulting educational goals were reviewed by a committee of Haitian and North American physician/medical education practitioners to reflect local needs. All authors reviewed lectures and then conferred to establish agreement on competencies presented for each lecture.

Results: Sixty-seven lectures were delivered. Human immunodeficiency virus/Acquired Immunodeficiency Syndrome, ophthalmologic, infectious diseases, renal and endocrine competencies were well-represented, with more than $50 \%$ of the joint AAFP and CFPC recommended competencies outlined. Areas under-represented included allergy and immunology, cardiology, surgery, pain management, gastroenterology, neurology, pulmonology, men's health and rheumatology; these topics accounted for less than $25 \%$ of AAFP/CFPC recommended competencies. Areas not covered included geriatrics, nutrition, occupational health and women's health. Within practice-based lectures, only disaster medicine, health promotion and information management were included, but only partially covered.
\end{abstract}

Conclusions: We identified teaching goals covered and competencies that were missing from a CME program for rural Haitian physicians. We aim to use this analysis to provide a competency-based CME lecture series that proportionally meets local needs while following recommendations of recognized national family medicine organizations.

Keywords: Global health, Medical education, Distance learning

\footnotetext{
* Correspondence: robert.battat@mail.mcgill.ca

${ }^{1}$ Department of Gastroenterology, McGill University Health Centre (MUHC),

1001 Decarie Blvd, D05-7161, Montreal H4A 3J1, Canada

Full list of author information is available at the end of the article
} 


\section{Background}

To meet the goals set by the Universal Declaration of Human Rights to promote health and ensure adequate access to medical care [1], health systems need to insure that health care providers are well-trained and competent [2]. Recent international calls for major reform in healthcare professional training have emphasized using competencybased curricula and information technology-empowered learning [3]. Competency-based curricula have become the preferred means of delivering medical education [3-5]. Unfortunately, those countries with the greatest healthcare needs often have the fewest educational resources to advance health care provider training [6].

Advanced communication and interactive distance learning tools provide unique opportunities to bring innovative educational resources to medical professionals in low-income or remote locations, thereby expanding global access to high-quality training programs $[3,7,8]$. Besides enabling access to educational materials and instructors, distance learning programs can assist with supporting relationships among medical professionals across distant locations and provide valuable opportunities for capacity building [9].

Continuing medical education (CME) has long been used in high-income settings to facilitate the ongoing acquisition of knowledge and skills by health care professionals with the aim of improving patient care [10]. Despite the important role CME programs have in maintaining physician accreditation in high-income countries, there currently have been few opportunities for ongoing CME in low-income countries $[11,12]$.

The Republic of Haiti, which occupies the western third of the Island of Hispaniola, is one of the poorest countries in the Americas [13]. Haitian health indices are the lowest ranking in the Western Hemisphere and amongst the lowest in the world [14-17]. Despite a long tradition of medical education in Haiti, medical education resources remain inadequate to meet the country's needs [14-18]. Haitian physicians have expressed a lack access to professional development programs and CME activities [6]. The Haiti Medical Education (HME) Project, a non-profit organization, works in alliance with Haitian medical leadership, faculty and students to support the Country's medical education system by bringing together healthcare providers, academics and social activists across multiple countries to work towards restoring and building upon the infrastructure and curricula of Haitian medical schools and teaching hospitals [19-23].

One area of active effort for HME and its Haitian and international partners has been the establishment of CME opportunities for practicing physicians. Currently, there is no published literature addressing competency based curricula delivery through distance learning in developing countries. We present the creation, delivery and evaluation of the early stages of a competency-based CME curriculum for physicians working in rural Haiti using videoconferencing technologies to provide a series of lectures from locally and internationally-based experts and supported by local academic clinical programs.

\section{Methods \\ Distance learning tools}

Prior to the initiation of this lecture series in April 2011, individual hospitals held local teaching session, but no multi-site lecture series existed at rural sites. In order to reach Haitian physicians based at remote rural sites, VidyoConferencing ${ }^{\text {mi }}$ technology was used for teleconferencing lectures in real time from international institutions to the training locations. High-quality audiovisual lectures were provided to multiple sites, despite limited Internet connectivity. Participants could ask questions directly to the instructor or to colleagues across the linked sites during the presentation. Lectures were delivered probono by academically affiliated experts from Haiti or abroad.

\section{Establishing competencies}

Lectures initially were given based on lecturer availability without predetermined competency-based educational objectives. To provide more relevant and targeted CME materials for our audience, a competency-derived CME curriculum was created, with the aim of structuring our course with pre-determined competencies. This process included analyzing the presentations that had been given to date to determine those competencies that had been delivered and those that had not.

Using the American Academy of Family Physicians (AAFP) and College of Family Physicians Canada (CFPC) guidelines as references [24, 25] a competency-derived syllabus was created for a Haitian continuing medical education program. AAFP and CFPC competencies were categorized by topic area (e.g., cardiology, infectious disease, public health, etc.), and then 38 AAFP defined competency areas were abstracted and reorganized to create a baseline set of lecture topics and learning objectives. This initial set was then crossreferenced using the CFPC competency guidelines to identify additional areas for inclusion. The resulting educational goals were reviewed by a committee of Haitian and North American physician/medical education practitioners (RB, CR, LW, MJ, MN, TFB and GS) to ensure that the final set of competency objectives were appropriate for local Haitian practice needs (Fig. 1). Forty-four competency domains, broadly divided into "disease-based competencies" and "practicebased competencies" for organizational purposes were created (http://www.hmeproject.org/competencyexcel/). For the purposes of this program, a competency was 


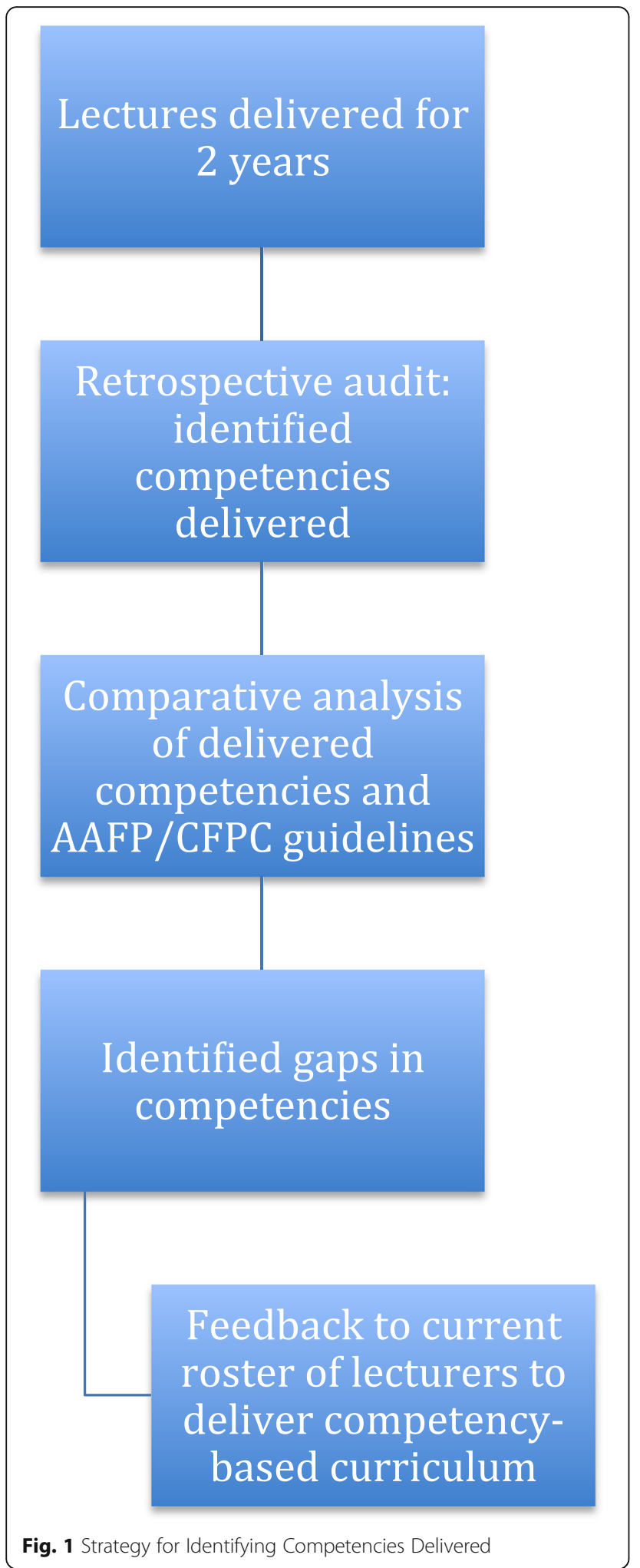

defined as "the habitual and judicious use of communication, knowledge, technical skills, clinical reasoning, emotions, values, and reflection in daily practice for the benefit of the individual and the community being served" [26].

\section{Audit of delivered competencies}

To assess the coverage of competency-based learning objectives, each lecture was analyzed individually and separately by two reviewers (RB, CR, LW, MJ, MN, TFB or GS), who were blinded to the other's evaluation. This analysis was performed for of recordings of online videolectures delivered from April 1st 2011 to January 1st 2013. Competencies delivered in these lectures were identified using the established AAFP/CFPC competency syllabus. Furthermore, delivered competencies were then crossreferenced with this syllabus. Competencies that were expected based on the presentation topic but not covered in the lecture also were noted. The reviewers then conferred to establish agreement on competencies presented for each reviewed lecture. In the cases where the 2 reviewers did not reach consensus, a separate senior reviewer (GS) adjudicated discrepancies.

\section{Results}

Sixty-seven lectures were delivered between April 1st 2011 and January 1st 2013. Lectures delivered, lecturer information and affiliations are outlined in Table 1. Sixty-three lectures addressed disease-based competencies and 4 lectures addressed practice-based competencies. Competencies delivered were compared to the established AAFP/CFPC competency syllabus (Table 2).

Within disease based lectures, human immunodeficiency virus/Acquired Immunodeficiency Syndrome (HIV/AIDS), ophthalmologic, general infectious diseases, renal and endocrine competencies were well-represented; together these subjects covered more than $50 \%$ of the joint AAFP and CFPC recommended competencies outlined. Recommended competency areas under-represented in the lecture series included allergy and immunology, cardiology, surgery, pain management, gastroenterology, neurology, pulmonology, men's health and rheumatology; together these topics accounted for less than $25 \%$ of AAFP/CFPC recommended competencies. Recommended competency areas not covered included geriatrics, nutrition, occupational health and women's health. In general, when a specific topic area was covered by a lecture, the majority of recommended joint AAFP/CFPC learning goals for that topic area were presented. Within practice-based lectures, only disaster medicine, health promotion and information management were included in lectures; however, the competency goals for these topics were only partially covered. Recommended practice-based topics not covered by lecturers are listed in Table 2 .

A full outline of competencies covered, by competency area, is available on HME website (http://www.hme project.org/competencyanalysis/). 
Table 1 Lectures and Competency Areas Delivered

\begin{tabular}{|c|c|c|c|}
\hline Competency area & $\begin{array}{l}\text { Physician lecturer } \\
\text { name }\end{array}$ & Lecturer affiliation & Lecture title: \\
\hline \multirow[t]{5}{*}{ Cardiology } & Martin Sedlacek & Dartmouth University & Hypertension-Blood Pressure \\
\hline & Juan Carlos Chirgwin & McGill University & $\begin{array}{l}\text { (1) Hypertension - Risk Factors, Screening, Investigations } \\
\text { (2) Hypertension - Therapy }\end{array}$ \\
\hline & Jocelyne David & University of Miami & (1) Heart Failure (2) Pre-operative evaluation \\
\hline & Joseph Valery Andre & St. Vincent Medical Center & $\begin{array}{l}\text { Secondary Hypertension: Etiology, Diagnosis and } \\
\text { Management }\end{array}$ \\
\hline & Brian Remillard & Dartmouth University & (1) Hypertension (2) Hypertensive Emergencies \\
\hline \multirow[t]{2}{*}{ Endocrinology } & Kaberi Dasgupta & McGill University & Management of Type II Diabetes \\
\hline & David Morris & McGill University & Thyroid Disease \\
\hline \multirow{6}{*}{$\begin{array}{l}\text { Urgent and Emergent } \\
\text { Care }\end{array}$} & Robert Harris & Dartmouth University & Abdominal Emergencies with Ultrasound \\
\hline & Robert Hyde & Dartmouth University & Anaphylaxis \\
\hline & Joseph Valery Andre & St. Vincent Medical Center & The Recognition and Management of Shock States \\
\hline & Dickens Saint-Vil & Université de Montreal & Prise en charge des traumas pédiatriques \\
\hline & Thomas Joseph Lydon & Wentworth-Douglass Hospital & Therapeutic Hypothermia \\
\hline & Jacques Stanley Elysse & Laval University & Prise en charge des AVC ischmiques \\
\hline Family Medicine & Pierre Paul-Tellier & McGill University & Men's Health \\
\hline Hematology & Cruff Renard & $\begin{array}{l}\text { Albert Einstein College of } \\
\text { Medicine }\end{array}$ & (1) Anemia (2) Sickle Cell Anemia \\
\hline \multirow[t]{7}{*}{ Infectious Diseases } & Tim Brewer & McGill University & Cellulitis \\
\hline & Selim Rashed & Université de Montreal & $\begin{array}{l}\text { (1) Malaria (2) Giardiasis and Amebiasis (3) Dengue } \\
\text { (4) Giardiasis and Filiariasis }\end{array}$ \\
\hline & $\begin{array}{l}\text { Marie- Josée } \\
\text { Brouillette }\end{array}$ & McGill University & $\begin{array}{l}\text { Cognitive disorders associated with HIV infection and their } \\
\text { impact on the treatment of HIV }\end{array}$ \\
\hline & Makeda Semret & McGill University & Acute Meningitis \\
\hline & Jodie Dionne-Odom & Dartmouth University & $\begin{array}{l}\text { (1) HIV PEP/PreP (2) STIs - Gonorrhea, Chlamydia, } \\
\text { Syphilis and HPV }\end{array}$ \\
\hline & Mark Wainberg & McGill University & $\begin{array}{l}\text { (1) Pharmacoresistance to HIV (2) Understanding } \\
\text { HIV Drug Resistance }\end{array}$ \\
\hline & Pierre Paul-Tellier & McGill University & Sexually Transmitted Infections \\
\hline \multirow[t]{5}{*}{ Nephrology } & Brian Remillard & Dartmouth University & Acute Renal Failure \\
\hline & Michelle Elizov & McGill University & Acute Kidney Injury \\
\hline & Serge Quérin & Université de Montreal & Dysnatrémies et dyskaliémies: approche pratique \\
\hline & Brian Remillard & Dartmouth University & L'hemodialyse de suppleance \\
\hline & Martin Sedlacek & Dartmouth University & $\begin{array}{l}\text { Urinalysis and its use as a diagnostic and } \\
\text { management measure }\end{array}$ \\
\hline \multirow{4}{*}{$\begin{array}{l}\text { Obstetrics and } \\
\text { Gynecology }\end{array}$} & David Morris & McGill University & Diabetes in Pregnancy \\
\hline & Thomas Lydon & Wentworth-Douglass Hospital & First-Trimester Vaginal Bleeding \\
\hline & Roger Duvivier & $\begin{array}{l}\text { Albert Einstein College of } \\
\text { Medicine }\end{array}$ & $\begin{array}{l}\text { (1) Prevention of Maternal Mortality } \\
\text { (2) La mortalité maternelle en Haiti }\end{array}$ \\
\hline & Daniel Blouin & Université de Sherbrooke & Porblemes Obstetricaux \\
\hline \multirow[t]{2}{*}{ Oncology } & Thierry Alcindor & McGill University & $\begin{array}{l}\text { (1) Colon Cancer (2) Chimiothérapie-Principes } \\
\text { de base }\end{array}$ \\
\hline & Robert Fine & Columbia University & Pancreatic Cancer \\
\hline Opthalmology & Franz Large & Haitian Society of Opthalmology & What every doctor must know about Opthalmology \\
\hline Orthopedics & Marc Rambaud & Centre hospitalier de Sens, France & $\begin{array}{l}\text { (1) Orthopedic Issues \& Case Discussion } \\
\text { (2) Les fractures bi-Malléolaires, Orthopedic } \\
\text { Issues \& Case Discussion }\end{array}$ \\
\hline
\end{tabular}


Table 1 Lectures and Competency Areas Delivered (Continued)

\begin{tabular}{|c|c|c|c|}
\hline \multirow[t]{5}{*}{ Other } & Galit Sacajiu & $\begin{array}{l}\text { Albert Einstein College Of } \\
\text { Medicine }\end{array}$ & Reading the Literature - Clinical Epidemiology Workshop \\
\hline & Pierre Minn & $\begin{array}{l}\text { University of California, } \\
\text { San Francisco }\end{array}$ & La Recherche Qualitative \\
\hline & Alison Doucet & McGill University & Pain Management \\
\hline & Pierre Paul-Tellier & McGill University & Testicular Mass \\
\hline & Thomas Minde & McGill University & Médecine Corps-Ėsprit (Médecine Psychosomatique) \\
\hline \multirow[t]{4}{*}{ Pediatrics } & Pia Wintermark & McGill University & $\begin{array}{l}\text { (1) Common Neonatal Brain Injuries (2) Management } \\
\text { of a newborn with hypoxic-ischemic encephalopathy } \\
\text { (3) Management of Low-Birth Weight Infants }\end{array}$ \\
\hline & Harris Huberman & State University of New York & $\begin{array}{l}\text { Autistic Spectrum Disorder and its identification } \\
\text { and management as it might apply in the context } \\
\text { of Haiti }\end{array}$ \\
\hline & Andrea Gorgos & McGill University & Pediatric follow-up of premature baby \\
\hline & Shuvo Ghosh & McGill University & Language Development in Children \\
\hline \multirow[t]{2}{*}{ Psychiatry } & Katlyne Lubin & $\begin{array}{l}\text { Albert Einstein College Of } \\
\text { Medicine }\end{array}$ & Cognitive-Adaptive Abilities \\
\hline & Marc Laporta & McGill University & Mental Health post-Emergency/Natural Disaster \\
\hline Respirology & Ron Olivenstein & McGill University & $\begin{array}{l}\text { (1) Asthma: Guidelines for Diagnosis and Therapy } \\
\text { (2) COPD/Emphysema }\end{array}$ \\
\hline \multirow[t]{3}{*}{ Rheumatology } & Marshall Fleurant & Boston University & $\begin{array}{l}\text { (1) Shoulder Pain (2) Back Pain - Outpatient Management } \\
\text { and Diagnosis }\end{array}$ \\
\hline & Marc Rambaud & Centre hospitalier de Sens, France & $\begin{array}{l}\text { (1) Arthrose du genou, (2) La hanche de l'enfant } \\
\text { (the hip of the child) }\end{array}$ \\
\hline & Lucie Brazeau & Université de Sherbrooke & $\begin{array}{l}\text { Quelques indices sur les RX de l'épaule, utiles au } \\
\text { raisonnement clinique á propos de l'épaule }\end{array}$ \\
\hline
\end{tabular}

\section{Conclusions}

Competency-based medical education is useful for initiating and maintaining targeted continuing medical education learning. A collaboration between Haitian and North American physicians led to a live distance learning CME program available to physicians in rural Haiti delivered via video conferencing technology. Using an educational syllabus jointly derived from AAFP and CFPC competencies for family physicians, 67 lectures were provided covering greater than $50 \%$ of AAFP and CFPC recommended competencies. Within each topic area presented, lecturers succeeded in covering specific teaching points completely.

Having the syllabus was valuable in identifying several competency areas recommended for family physicians but that were underrepresented in the lectures. Examples of topics not covered by lectures by recommended by the guidelines included acute coronary syndromes, management of weight loss, breast diseases and meningitis. While lecturer availability was the primary constraint for deciding which topics were presented, finding ways to present the range of recommended topics will be important in the future to ensure that participants are exposed to the gamut of topic areas needed to be a well-rounded family physician.

Expanding presentations of the practice-oriented competencies also needs to be done; for example, only mental health in disasters was discussed among the recommended disaster management topics. Skill-based competencies, such as Advanced Cardiac or Trauma Life Support, also were not included. As the program develops, establishing skill-based competencies using distance learning technologies will be a major challenge to be overcome.

Finally, it is notable that no global health topics such as burden of disease, migration and travel, social determinants of health, or health as a human right were discussed. While global health topics are expanding in North American undergraduate and graduate medical education, these topics also are increasingly important for postgraduate medical education in other high-income and middle/lowincome regions [5, 27, 28]. Global health root cause analysis with an emphasis on social justice is already underway in Haiti [29]; however, continued education and widening the audience for this topic would be valuable.

This analysis demonstrated the value of having competency-based curriculum to identify teaching goals covered and competencies that were missing from a CME program for rural Haitian physicians run over approximately 18 months. We aim to use this analysis to target future lecturer recruitment to provide a competencybased CME lecture series that proportionally meets local needs while following recommendations of recognized 
Table 2 Evaluation of Competencies Deliverered

\begin{tabular}{|c|c|c|c|c|c|}
\hline \multicolumn{6}{|l|}{ Disease based lectures } \\
\hline Competency area & $\begin{array}{l}\text { Topic areas } \\
\text { (\% of AAFP/CFPC competencies) }\end{array}$ & & For each topic area & Lectures (n) & Total lectures (\%) \\
\hline Adolescent & & $\begin{array}{l}\text { Overlap with Other } \\
\text { Topics }\end{array}$ & & 0 & \\
\hline Allergy & $14 \%$ & & $67 \%$ & 2 & $3 \%$ \\
\hline Cardiology & $21 \%$ & & $89 \%$ & 7 & $10 \%$ \\
\hline Infants and Childern & $31 \%$ & & $100 \%$ & 6 & $9 \%$ \\
\hline Older Adults & & Not Covered & & 0 & $0 \%$ \\
\hline Critical Care & & $\begin{array}{l}\text { Overlap with Other } \\
\text { Topics }\end{array}$ & & 1 & $1 \%$ \\
\hline Surgical & $7 \%$ & & $56 \%$ & 2 & $3 \%$ \\
\hline Pain & $13 \%$ & & $44 \%$ & 1 & $1 \%$ \\
\hline Endo & $53 \%$ & & $89 \%$ & 3 & $4 \%$ \\
\hline Eye & $52 \%$ & & $67 \%$ & 3 & $4 \%$ \\
\hline Gl & $20 \%$ & & $44 \%$ & 1 & $1 \%$ \\
\hline Neuro & $10 \%$ & & $100 \%$ & 2 & $3 \%$ \\
\hline Resp & $16 \%$ & & $89 \%$ & 2 & $3 \%$ \\
\hline Heme & $38 \%$ & & $67 \%$ & 2 & $3 \%$ \\
\hline HIV/AIDS & $100 \%$ & & N/A & 3 & $4 \%$ \\
\hline Human Behaviour & $55 \%$ & & $78 \%$ & 3 & $4 \%$ \\
\hline ID & $79 \%$ & & $100 \%$ & 7 & $10 \%$ \\
\hline Mat and Gyne & $36 \%$ & & $33 \%$ & 5 & $7 \%$ \\
\hline Mens Health & $15 \%$ & & $0 \%$ & 2 & $3 \%$ \\
\hline Muscoloskeletal & $44 \%$ & & $100 \%$ & 2 & $3 \%$ \\
\hline Nutrition & & Not Covered & & 0 & $0 \%$ \\
\hline Occupational & & Not Covered & & 0 & $0 \%$ \\
\hline Renal & $59 \%$ & & $78 \%$ & 3 & $4 \%$ \\
\hline Rheum & $8 \%$ & & $91 \%$ & 2 & $3 \%$ \\
\hline Emerg & $31 \%$ & & $100 \%$ & 4 & $6 \%$ \\
\hline Womens Health & & Not Covered & & 0 & $0 \%$ \\
\hline \multicolumn{6}{|l|}{ Practice Based Lectures } \\
\hline Disaster Medicine & $6 \%$ & & N/A & 1 & $1 \%$ \\
\hline Global Health & & Not Covered & & 0 & $0 \%$ \\
\hline Graduate Medical Education & & Not Covered & & 0 & $0 \%$ \\
\hline Health Promotion & $19 \%$ & & N/A & 1 & $1 \%$ \\
\hline Info Management & $91 \%$ & & N/A & 2 & $3 \%$ \\
\hline Leadership & & Not Covered & & 0 & $0 \%$ \\
\hline Management of Health Systems & & Not Covered & & 0 & $0 \%$ \\
\hline Medical Ethics & & Not Covered & & 0 & $0 \%$ \\
\hline Medical Informatics & & Not Covered & & 0 & $0 \%$ \\
\hline Office Laboratory & & Not Covered & & 0 & $0 \%$ \\
\hline Patient Education & & Not Covered & & 0 & $0 \%$ \\
\hline Practice Based Learning & & Not Covered & & 0 & $0 \%$ \\
\hline Risk Management and Medical Liability & & Not Covered & & 0 & $0 \%$ \\
\hline Urban Practice Curriculum & & Not Covered & & 0 & $0 \%$ \\
\hline
\end{tabular}


national family medicine organizations. Further, with a competency based lecture series, curriculum evaluations can be performed. An ancillary benefit of this collaboration has been the bi-directional learning for all participants involved in this partnership. Lecturers not only offer a service through providing high-quality lectures, but they also gain important experience through participating in long-term partnerships with Haitian colleagues. This lecture series presents an innovative approach to delivering CME to lowincome country primary care providers in remote areas that could be adapted by for other locations.

\section{Abbreviations}

AAFP: Academy of Family Physicians; CFPC: College of Family Physicians Canada; CME: Continuing medical education; HME Project: Haiti Medical Education Project

\section{Acknowledgements}

None.

\section{Funding}

No Sources of funding were required for the research performed in this study.

\section{Availability of data and materials}

Provided in the last paragraph of results section.

\section{Authors' contributions}

RB Study conception, study design, data collection and analysis, manuscript creation. MJ Data collection and analysis, manuscript creation. LW Data collection and analysis, manuscript creation. CR Data collection and analysis, manuscript creation. LH Data collection and analysis, manuscript creation. MN Data collection and analysis, manuscript creation. BR Data collection and analysis, manuscript creation. TFB Study Conception, study design, manuscript creation. GS Study Conception, study design, data collection and analysis, manuscript creation. All authors read and approved the final manuscript.

\section{Competing interests}

The authors declare that they have no competing interests. This includes both financial and non-financial competing interests.

\section{Consent for publication}

Not Applicable.

This manuscript does not contain any individual persons data.

\section{Ethics approval and consent to participate}

Not Applicable: This study did not conduct experiments on animal or human participants to provide animal or human data or tissue.

\begin{abstract}
Author details
'Department of Gastroenterology, McGill University Health Centre (MUHC) 1001 Decarie Blvd, D05-7161, Montreal H4A 3J1, Canada. ${ }^{2}$ Service Medecine Interne, Hopital Universite d'Etat d'Haiti, Port-au-Prince, Haiti. ${ }^{3}$ Department of Medicine, McGill University, Montreal, Canada. ${ }^{4}$ Department of Hospital Medicine, St Elizabeth Medical Center, Edgewood, KY, USA. ${ }^{5}$ Department of Internal medicine, McGill University, Montreal, Canada. ${ }^{6}$ Department of Family Medicine, Hopital St. Nicolas, St Marc, Haiti. ${ }^{7}$ Dartmouth Hitchcock Medical Center, One Medical Center Drive, Lebanon, NH, USA. ${ }^{8}$ Department of Medicine, David Geffen School of Medicine, University of California Los Angeles, Los Angeles, USA. ${ }^{9}$ ARC Health Resources, Congers, NY, USA.
\end{abstract}

Received: 8 April 2016 Accepted: 8 October 2016

Published online: 19 October 2016

\section{References}

1. The Universal Declaration of Human Rights. J Health Phys Ed Recreation. 1968;39(3):37-38.
2. Garcia-Barbero M. Medical education in the light of the World Health Organization Health for All strategy and the European Union. Med Educ. 1995;29(1):3-12.

3. Frenk J, Chen L, Bhutta ZA, et al. Health professionals for a new century: transforming education to strengthen health systems in an interdependent world. Lancet. 2010;376(9756):1923-58.

4. Frank JR, Snell LS, Cate OT, et al. Competency-based medical education: theory to practice. Med Teach. 2010;32(8):638-45.

5. Battat R, Seidman G, Chadi N, et al. Global health competencies and approaches in medical education: a literature review. BMC Med Educ. 2010;10:94.

6. Nadas M, Bedenbaugh R, Morse M, McMahon GT, Curry CL. A needs and resource assessment of continuing medical education in Haiti. Annals of global health. 2015;81(2):248-54.

7. Harden RM. A new vision for distance learning and continuing medical education. J Contin Educ Heal Prof. 2005;25(1):43-51.

8. Bates J FH, Schrewe B, Jamieson J, Ellaway R. Distributed Education and Distance Learning in Postgraduate Medical Education. Members of the FMEC PG consortium. 2011.

9. Remillard $\mathrm{BD}$, Buteau $\mathrm{JH}$, Cleophat P. Kidney care in Haiti-the role of partnerships. Nature reviews Nephrology Mar. 2015;11(3):183-8.

10. Shojania KG, Silver I, Levinson W. Continuing medical education and quality improvement: a match made in heaven? Ann Intern Med. 2012:156(4):305-8.

11. Hudspeth J, Curry CL, Sacks Z, Surena C. Continuing professional development in Low-resource settings: Haiti as example. Annals of global health. 2015;81(2):255-9.

12. Bagayoko CO, Perrin C, Gagnon MP, Geissbuhler A. Continuing distance education: a capacity-building tool for the de-isolation of care professionals and researchers. J Gen Intern Med. 2013;28 Suppl 3:S666-70.

13. Chelala CMD. The Challenge of Haiti. Health a Right for All: Pan American Health Organization, Regional Office of the World Health Organization; 2009.

14. The World Factbook: Central Intelligence Agency. Washington, DC, USA: Directorate of Intelligence; 2013.

15. Haiti: country profiles. 2011; http://www.who.int/gho/countries/hti.pdf Accessed 27 Dec 2013.

16. United Nations Children's Fund State of the world's children. 2011; http:// www.unicef.org/sowc2011/index.php. Accessed 27 Dec 2013.

17. Tappero JW, Tauxe RV. Lessons learned during public health response to cholera epidemic in Haiti and the Dominican Republic. Emerg Infect Dis. 2011;17(11):2087-93.

18. Mullan F. The metrics of the physician brain drain. N Engl J Med. 2005; 353(17):1810-8.

19. Riviello R, Ozgediz D, Hsia RY, Azzie G, Newton M, Tarpley J. Role of collaborative academic partnerships in surgical training, education, and provision. World J Surg. 2010;34(3):459-65.

20. Chin-Quee A, White L, Leeds I, MacLeod J, Master VA. Medical student surgery elective in rural Haiti: a novel approach to satisfying clerkship requirements while providing surgical care to an underserved population. World J Surg. 2011:35(4):739-44.

21. Haiti Medical Education Project. 2013; http://www.hmeproject.org/. Accessed 28 Dec 2013

22. Medical Education and Leadership Development Project (MELD). Brown University Global Health Initiative 2013; http://brown.edu/initiatives/globalhealth/haiti/medical-education-and-leadership-development-project-meld. Accessed 28 Dec 2013.

23. Haiti: Rebuilding Medical Schools. University of Calgary Global Health and International Partnerships 2013; http://www.ucalgary.ca/ghealth/projects/ haiti. Accessed 28 Dec 2013.

24. Defining competence for purposes of certification by the College of Family Physicians of Canada: The evaluation objectives in family medicine. 2010. http://www.cfpc.ca/uploadedFiles/Education/ DefiningCompetenceCompleteDocumentbookmarked.pdf, 2015

25. Family Medicine Residency Curriculum Guidelines. 2015; http///uww.aafp.org/ medical-school-residency/program-directors/curriculum.html. Accessed 28 Dec 2013.

26. Epstein RM. Assessment in medical education. N Engl J Med. 2007;356(4):387-96

27. Arthur MA, Battat R, Brewer TF. Teaching the basics: core competencies in global health. Infect Dis Clin N Am. 2011;25(2):347-58.

28. Archer N, Moschovis PP, Le PV, Farmer P. Perspective: postearthquake haiti renews the call for global health training in medical education. Acad Med. 2011;86(7):889-91.

29. Marsh RH, Rouhani SA, Pierre P, Farmer PE. Strengthening emergency care: experience in central Haiti. Lancet Global health. 2015;3 Suppl 2:S5-7. 